\title{
Impact of Ethical Leadership and Mediating Effect of Organization Culture on Employees Performance: A Case of SSGC Zonal Office District Jacobabad Sindh, Pakistan
}

\author{
Sadam Hussain and Arifa BanoTalpur
}

\section{ABSTRACT}

\begin{abstract}
Ethical Leadership plays a vital role in every organization and is always seen as a positive perspective both in research and in practice and predicts the relation of employee performance and mediating role of organizational culture.

The present research is conducted in a domestic public listed company named Sui Southern Gas Company (SSGC). The research was conducted for the purpose of evaluating the role of ethical leaders, followers who act and behave ethically, this paper presumes the high and low levels of ethical leadership and would show the positive and negative aspects of executives over employee performance and how organizational culture mediates and is affected by ethical leaders. In this paper primary resources were used, for the primary purpose, the questionnaire was spread to know the impacts of ethical leadership on employee performance and how organization culture mediates within SSGC.
\end{abstract}

Keywords: Ethical leadership, organization culture employee's performance.

\section{INTRODUCTION}

The key to a successful organization is to have a culture and ethical leadership based on a strongly held and widely shared set of beliefs that are supported by strategy and structure.

Mediating effect of organizational culture is very important and plays greater role in aligning member with organization's purpose. So, compatibility of goals and way of thinking drives the members to perform well, be self-directed, and be loyal to the organization they belong to. Conversely, organization and its leadership can fall down due to ineffective culture.

The employee's disengagement, ineffective relations with customers, high turnover and lower profits are examples of the wrong culture which brings negative impact on the bottom line. For large scale company organization culture is mandatory to hold a tight grip in this modern era to which ethical leadership can only handle with intensive care and proper check. The company has diversified workforce which provides opportunities as well as challenges, therefore this research attempts to this study the impact of ethical leaders on employee performance and mediating effect of organization culture. Strong culture in SSGC lets three things to happen: Employees are aware that how to respond to any situation as they know what top management wants, so the expected response seems to be the proper one, and employees get rewarded for demonstration.

\author{
Submitted : March 10, 2021 \\ Published : March 31, 2021 \\ ISSN: 2507-1076 \\ DOI: $10.24018 /$ ejbmr.2021.6.2.810 \\ Sadam Hussain * \\ Mehran University Institute of Science, \\ Technology and Development (MUISTD), \\ MUET, Jamshoro, Pakistan. \\ (e-mail: sadambrohi111@ gmail.com) \\ Dr. Arifa BanoTalpur \\ Assistant Professor \\ Mehran University Institute of Science, \\ Technology, and Development \\ (MUISTD), MUET, Jamshoro, Pakistan. \\ (e-mail: arifa.talpur@faculty.muet.edu.pk) \\ *Corresponding Author
}

\section{A. Ethical Leadership Can Be Described with Variety of Ways}

Ethical leaders in Kanungo [1] are rational in decisionmaking, engaging in actions and activities that favor workers while avoiding negative behaviors that hurt other employees or organizations.

Brown, Treviño, and Harrison [2]: fair treatments, ethical standards, integrity of leader and involving others in decision making makes him more efficient as cornerstones of ethical leadership are said to be employees.

Treviño and Brown [3]: ethical leader practices what he preaches, promotes his ethical conduct, makes accountable to everyone, and manages ethics.

Morality plays a crucial role in ethical leadership in Khuntia and Suar [4], so an ethical leader needs to integrate ideals into their values, convictions, and actions. The area of ethical leadership, which includes humility, integrity, altruism, fairness, and justice, is broad.

These values are reflected by behaviors of ethical leadership. Which are said to be that ethical leader is very supportive in nature and helps employee when they face any problem, fairly treats employees so everyone can get equal rewards and benefits, he is honest and straight forward in communicating to employees, makes sacrifices, and delivers importance of values and ethical standards for work.

Relations-oriented behavior which constructs in the leadership literature states that leader is supportive, develops subordinate skills, empowers leadership, self-confidence and 
represents the subordinate interests which are overlapped by ethical leadership [5].

\section{B. Organization Culture}

"Organizational culture is the combination of expectations of organization, experiences, philosophy and values". Organizational culture is also called corporate culture. Productivity and performance of any organization is influenced by Organizational culture as it provides punctuality, quality of product and safety guidelines. Organization culture is network of work functions done in an organization so that is why it is said to be unusual and problematic to change [6].

As defined earlier [7] that performance of any organization is combination of skilled work and sustainable work environment. So, the motivation plays vital role in enhancing the performance of employees because productivity comes from effective motivation. It can come from rewards, salaries, and other incentives. It shows to employees that how committed the organization is in fulfilling the goals and objectives. The committed organization is also committed to employee enhancement invests in their skills, offers good pays and allowances to make them secure, educational expenses and training which keeps them updated with modern capabilities.

\section{Employee Performance}

A successful company must have a good corporate culture and the success of employees is the fundamental element of any organization's moral enhancement. It because of dependency on employee as employees are building blocks of organization while one or two employees cannot change the destiny of organization there needs to be bulk to bring revolution. So, the performance of organization is combined struggle of all employees working in organization. "Performance is the key multi character factor intended to attain outcomes which has a major connection with planned objectives of the organization" [8].

To reach any higher rank leaders and employees' contribution in performance and contribution is must and to achieve organizational goals and objectives there should be utilization of capabilities. Because organization expect a good contribution from leaders and employees. The dependency is interchangeable as in many cases employees are accountable to fulfill these expectations whereas in some exceptional cases employees become unable to do so then they depend on bosses and management for proper guideline. Therefore, the personal development and training of employee is so mandatory to show performance, accomplish organizational goals and responsibilities diligently. Here commonly a question is raised that how an employee can be competent and efficient for improving performance, modernism, and productivity. In assistance to discovering and polishing leadership, efficiency in leadership plan is said to be strong weapon in support between employees [9].

\section{Aim of the Study}

The study aims to find out impact of ethical leadership and mediating effect of organization culture on employee's performance.

\section{E. Objectives:}

1 To analyze effect of Ethical leadership on employee's performance of SSGC of Pakistan.

2 To examine the mediating role of organizational culture between ethical leadership and employees Performance.

\section{LITERATURE REVIEW}

In any corporate industry plays important role in employee retention, positive culture retains employee and vice versa [10]. There is high employment retention rate where organization provides good organization culture in a competitive era [11].

The interest in studying ethical leadership increased when repeated scandals happened in the past decade involving public and corporate sector leaders [12].

Relations-oriented behavior which constructs in the leadership literature states that leader is supportive, develops subordinate skills, empowers leadership, self-confidence and represents the subordinate interests which are overlapped by ethical leadership [13].

Study shows that morality plays a vital role in ethical leadership, so an ethical leader has to incorporate principles in their values, beliefs, and behaviors. The domain constructed around ethical leadership is broad which includes compassion, honesty, altruism, fairness, and justice. These values are reflected by behaviors of ethical leadership. Which are said to be that ethical leader is very supportive in nature and helps employee when they face any problem, fairly treats employees so everyone can get equal rewards and benefits, he is honest and straight forward in communicating to employees, makes sacrifices, and delivers importance of values and ethical standards for work [14].

To reach any higher rank leaders and employees' contribution in performance and contribution is must and to achieve organizational goals and objectives there should be utilization of capabilities. Because organization expects a good contribution from leaders and employees. The dependency is interchangeable as in many cases employees are accountable to fulfill these expectations whereas in some exceptional cases employees become unable to do so then they depend on bosses and management for proper guideline [15].

A prosperous organization must have strong organization culture and the employee performance is the vital element which increases moral of any organization. It because of dependency on employee as employees are building blocks of organization while one or two employees cannot change the destiny of organization there needs to be bulk to bring revolution [16].

\section{HYPOTHESES OF THE STUDY}

Null and Alternate hypotheses of the study.

Ho1: there is non-significant impact of Ethical leadership on employee's performance.

Ha1: there is significant impact of Ethical leadership on employee's performance.

Ho2: there is not any mediating effect of organizational culture between ethical leadership and employee's 
performance.

Ha2: there is a mediating role of organizational culture between ethical leadership and employee's performance.

\section{A. Variables}

The variables set based on literature review and current study focus on Impact of ethical leadership \& mediating effect of organization culture on employee's performance:

a) Independent variable: Ethical Leadership.

b) Dependent Variable: Employees Performance.

c) Mediating Variable: Organization Culture.

\section{RESEARCH MATERIALS \& METHODS}

In this research methodology a single case study of SSGC regarding the ethical leadership and mediating effect of organization culture on employees' performance.

In this study used quantitative method approach, involves strong explanation, inferences and a clear image of problem under study, used in this study to gather the primary data on the case study to quantify the findings through this study taken a questionnaire with close ended questions where set of predefined answer option are given to choose between, to know either they agree with the answers or not and the questionnaires such as Ethical Leadership Questionnaire, Organizational Culture Questionnaire and task performance was measured through [17].

Through this study distributed 200 plus questionnaires to the respondents and gathered 193, out of which 7 questionnaires were not completed and those questionnaires were rejected because of knowledge shortage and incompleteness, so this study finally selected for data analysis 186 questionnaires.

This approach is used to provide the study with stronger explanation of phenomenon through study is trying to explore the preferred SSGC organization or segment.

Therefore, descriptive, and inferential statistics have been done to analyze the collected data.

The information and data received from the respondents was analyzed with the help of statistical software program (SPSS-25) Software Packages for Social Sciences and to check Mediating role of Organizational culture the help of Sobel test have been taken to get the results.

Ethical leadership can also have ramifications in the context of promotion, and ethical leaders are shown to be no more likely to be encouraging compared to less ethical behavior [18], but to evaluate the influence that poses the ethical leadership on organization this single case study is expected to produce some in-depth insights into ethical leadership and organization culture [19].

In the data collection process, case studies typically include surveys, interviews, observation, document analysis and analysis of archival documents [20].

This study mainly relied on survey done through a questionnaire based on liker-scale with 49 items under consideration to know the answers.

\section{RESUlTS AND DisCUSSION}

\section{A. Respondents Demographic Data}

TABLE I: AGE OF RESPONDENTS

\begin{tabular}{cccccc}
\hline \multicolumn{5}{c}{ TABLE I: AGE OF RESPONDENTS } \\
\hline Age of employees & Frequency & Percent & $\begin{array}{c}\text { Valid } \\
\text { Percent }\end{array}$ & $\begin{array}{c}\text { Cumulative } \\
\text { Percent }\end{array}$ \\
\hline \multirow{4}{*}{ 25 to 35 years } & 10 & 5.4 & 5.4 & 5.4 \\
35 to 45 & 81 & 43.5 & 43.5 & 48.9 \\
$\quad$ Years & & 51.1 & 51.1 & 100.0 \\
& 45 to 60 years & 95 & 100.0 & 100.0 & \\
\hline
\end{tabular}

TABLE II: EDUCATION OF RESPONDENTS

\begin{tabular}{|c|c|c|c|c|c|}
\hline \multicolumn{2}{|c|}{ Education of employees } & Frequency & Percent & $\begin{array}{c}\text { Valid } \\
\text { Percent }\end{array}$ & $\begin{array}{c}\text { Cumulative } \\
\text { Percent }\end{array}$ \\
\hline \multirow{7}{*}{ Valid } & $\begin{array}{c}\text { Postgraduate/ } \\
\text { Master }\end{array}$ & 24 & 12.9 & 12.9 & 12.9 \\
\hline & Bachelor & 40 & 21.5 & 21.5 & 34.4 \\
\hline & Intermediate & 100 & 53.8 & 53.8 & 88.2 \\
\hline & Diploma & 5 & 2.7 & 2.7 & 90.9 \\
\hline & Matric & 11 & 5.9 & 5.9 & 96.8 \\
\hline & Middle & 6 & 3.2 & 3.2 & 100.0 \\
\hline & Total & 186 & 100.0 & 100.0 & \\
\hline
\end{tabular}

TABLE III: JOB STATUS OF RESPONDENTS

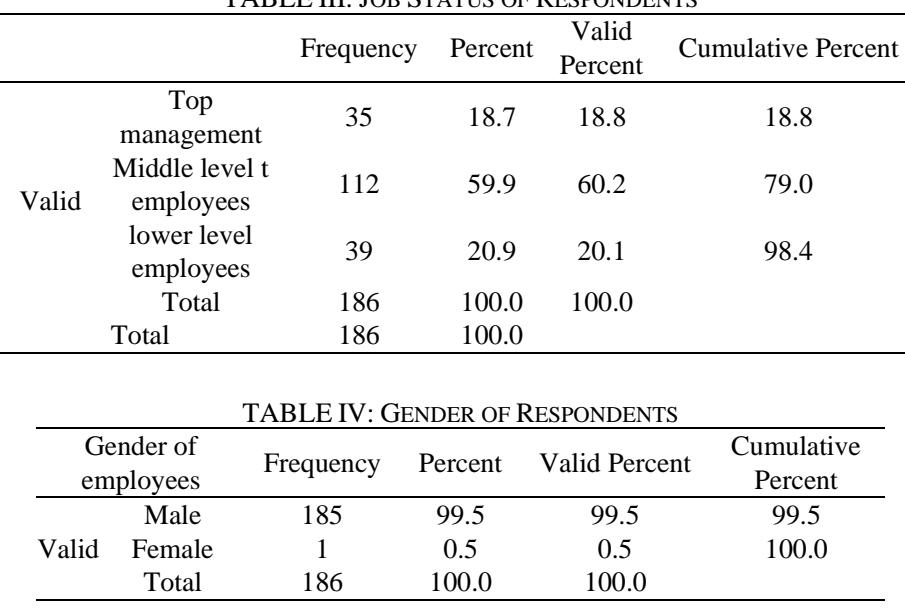

\section{B. Data Analysis}

Achieved Objective number one based on following.

Objective 1: To analyze effect of ethical leadership on employee's performance.

$$
\text { Em_performance }=\alpha+\beta(\text { El_leadership })+\varepsilon
$$

whereas

Em_performance $=$ Dependent Variable, indicate Employee's Performance.

El_leadership = Independent variable, shows Ethical leadership.

Table V provides statistical result for dependent variable Em_ performance and other independent variables is El_leadership. This analysis furnished the impact of independent variables on dependent variable.

Indicated $\mathrm{R}^{2}$ reflects the strength of regression model is 0.798 strong and absolute relationship between variables, $\mathrm{R}^{2}$ coefficient value show the goodness fit model and explain variation around the Em_performance and has probe value 0.000 is significant relationship between variables, $F$ value 323.483is statically significant and the Durbin-Watson value 1.875 . 
TABLE V: MODEL SUMMARY ${ }^{\mathrm{b}}$

\begin{tabular}{|c|c|c|c|c|c|c|c|c|c|c|}
\hline \multirow[b]{2}{*}{ Model } & \multirow[b]{2}{*}{$\mathrm{R}$} & \multirow[b]{2}{*}{$\begin{array}{c}\mathrm{R} \\
\text { Square }\end{array}$} & \multirow[b]{2}{*}{$\begin{array}{l}\text { Adjusted R } \\
\text { Square }\end{array}$} & \multirow[b]{2}{*}{$\begin{array}{l}\text { Std. Error of the } \\
\text { Estimate }\end{array}$} & \multicolumn{5}{|c|}{ Change Statistics } & \multirow[b]{2}{*}{$\begin{array}{l}\text { Durbin- } \\
\text { Watson }\end{array}$} \\
\hline & & & & & $\begin{array}{c}\text { R Square } \\
\text { Change }\end{array}$ & F Change & df1 & df 2 & $\begin{array}{c}\text { Sig. F } \\
\text { Change }\end{array}$ & \\
\hline 1 & $0.798^{\mathrm{a}}$ & 0.637 & 0.635 & 7.71640 & 0.637 & 323.483 & 1 & 184 & 0.000 & 1.875 \\
\hline
\end{tabular}

a. Predictors: (Constant), El_leadership.

b. Dependent Variable: Em_performance.

Table VI shows ANOVA of Em_performance result shows F value (323.483) and probe value 0.000 is statistically significant. There is a positively significant impact of El. leadership on employee's performance. Hence, alternatehypothesisHal is Accepted.

TABLE VI: ANOVA ${ }^{\mathrm{a}}$

\begin{tabular}{lcccccc}
\hline Model & Sum of Squares & Df & Mean Square & F & Sig. \\
\hline Regression & 19261.074 & 1 & 19261.074 & 323.483 & $0.000^{\mathrm{b}}$ \\
1 & Residual & 10955.878 & 184 & 59.543 & & \\
Total & 30216.952 & 185 & & & \\
\hline
\end{tabular}

Table VII shows that the results reflect the individual independent variable has statistically significant relationship or not with the dependent variable. The results show equation Em_performance Beta value 0.724 and probe value 0.00 Positive relationship with the El_leadership statistically significant.

Objective 2: To examine the mediating role of organizational culture on employee's performance.

$$
\text { Org_culture }=\alpha+\beta 1(\text { El_leadership })
$$

Em_performance $=\alpha+\beta 1$ (org_culture $)$

whereas,

Em_performance $=$ Dependent Variable, indicate Employee's Performance.

El_leadership= Independent variable, shows Ethical leadership.

Org_culture = Independent variable, Organizational culture.

Table VIII provides statistical result for dependent variable Em_performance and other independent variables is El_leadership. This analysis furnished the impact of independent variables on dependent variable.

Indicated $\mathrm{R}^{2}$ reflects the strength of regression model is 0.798 strong and absolute relationship between variables, $\mathrm{R}^{2}$ coefficient value show the goodness fit model and explain variation around the Em_performance and has probe value 0.000 is significant relationship between variables, $\mathrm{F}$ value 323.483is statically significant and the Durbin-Watson value 1.875 .

TABLE VII: COEFFICIENT

\begin{tabular}{|c|c|c|c|c|c|c|c|c|c|c|c|}
\hline & \multirow[t]{2}{*}{ Model } & \multicolumn{2}{|c|}{$\begin{array}{l}\text { Unstandardized } \\
\text { Coefficients }\end{array}$} & \multirow{2}{*}{$\begin{array}{c}\begin{array}{c}\text { Standardized } \\
\text { Coefficients }\end{array} \\
\text { Beta } \\
\end{array}$} & \multirow[t]{2}{*}{$\mathrm{T}$} & \multirow[t]{2}{*}{ Sig. } & \multicolumn{2}{|c|}{$95.0 \%$ Confidence Interval for B } & \multicolumn{3}{|c|}{ Correlations } \\
\hline & & $\mathrm{B}$ & Std. Error & & & & Lower Bound & Upper Bound & Zero-order & Partial & Part \\
\hline 1 & (Constant) & 22.208 & 1.963 & & 11.313 & 0.000 & 18.335 & 26.081 & & & \\
\hline
\end{tabular}

a Dependent Variable: Em_performance.

b Independent variable: El_leadership.

TABLE VIII: MODEL SUMMARY ${ }^{\mathrm{b}}$

\begin{tabular}{cccccccccccc}
\hline \multirow{2}{*}{ Model } & $\mathrm{R}$ & \multirow{2}{*}{$\begin{array}{c}\mathrm{R} \\
\text { Square }\end{array}$} & $\begin{array}{c}\text { Adjusted R } \\
\text { Square }\end{array}$ & $\begin{array}{c}\text { Std. Error of } \\
\text { the Estimate }\end{array}$ & $\begin{array}{c}\text { R Square } \\
\text { Change }\end{array}$ & F Change & df1 & df2 & $\begin{array}{c}\text { Sig. F } \\
\text { Change }\end{array}$ & Durbin-Watson \\
\hline 1 & $.863^{\mathrm{a}}$ & 0.745 & 0.744 & 8.72062 & 0.745 & 538.982 & 1 & 184 & 0.000 & 1.945 \\
\hline
\end{tabular}

a. Predictors: (Constant), El_leadership.

b. Dependent Variable: Org_culture.

Table IX shows ANOVA of Em_performance result shows $\mathrm{F}$ value (323.483) and probe value 0.000 is statistically significant. There is a positively significant impact of El_leadership on employee's performance. Hence, alternate hypothesis Ha1 is Accepted.

TABLE IX:ANOVA ${ }^{\mathrm{a}}$

\begin{tabular}{|c|c|c|c|c|c|}
\hline Model & Sum of Squares & Df & Mean Square & $\mathrm{F}$ & Sig. \\
\hline Regression & n 40989.198 & 1 & 40989.198 & 538.982 & $0.000^{\mathrm{b}}$ \\
\hline 1 Residual & 13993.060 & 184 & 76.049 & & \\
\hline Total & 54982.258 & 185 & & & \\
\hline
\end{tabular}

Table $\mathrm{X}$ shows that the results reflect the individual independent variable has statistically significant relationship or not with the dependent variable. The results show equation Em_performance Beta value 0.724 and probe value 0.00 Positive relationship with the El_leadership statistically significant.

The second objective's equation:

Em_performance $=\alpha+\beta 1$ (org_culture)

whereas

Em_performance $=$ Depended variable indicate Employee's performance.

Org_culture=Independent variable indicate organizational culture.

Table XI provides statistical result for dependent variable Em_performance and other independent variables is (org_culture). This analysis furnished the impact of independent variables on dependent variable. indicate $\mathrm{R}^{2}$ the dependent variable reflects the strength ofr egression model is 0.907 strong and absolute relationship between variables, $\mathrm{R}^{2}$ coefficient value show the goodness fit modeland explain 
variation around the in (Em_performance) and has probe value 0.000 is significant relationship between variables, $F$ value 850.833 is statically significant and the Durbin-Watson value 1.976 .

Table XII shows ANOVA of org_culture result shows F value (850.833) and probe value 0.000 is statistically significant. There is a positively significant impact of org_culture on Em_performance. Hence, alternate hypothesis
Ha1 is accepted.

Table XIII shows that the results reflect the individual independent variable has statistically significant relationship or not with the dependent variable. The results show equation 4 El_leadership Beta value 0.672 and probe value 0.00 Positive relationship with the Em_performance statistically significant.

TABLE X: COEFFICIENTS ${ }^{\mathrm{a}}$

\begin{tabular}{|c|c|c|c|c|c|c|c|c|c|c|c|}
\hline \multirow{2}{*}{\multicolumn{2}{|c|}{ Model }} & \multicolumn{2}{|c|}{$\begin{array}{c}\text { Unstandardized } \\
\text { Coefficients }\end{array}$} & \multirow{2}{*}{$\begin{array}{c}\begin{array}{c}\text { Standardized } \\
\text { Coefficients }\end{array} \\
\text { Beta }\end{array}$} & \multirow{2}{*}{$\mathrm{T}$} & \multirow{2}{*}{ Sig. } & \multicolumn{2}{|c|}{$95.0 \%$ Confidence Interval for B } & \multicolumn{3}{|c|}{ Correlations } \\
\hline & & B & Std. Error & & & & Lower Bound & $\begin{array}{l}\text { Upper } \\
\text { Bound }\end{array}$ & Zero-order & Partial & Part \\
\hline \multirow{2}{*}{1} & (Constant) & 14.584 & 2.218 & & 6.574 & 0.000 & 10.207 & 18.961 & & & \\
\hline & El_leadership & 1.057 & 0.046 & 0.863 & 23.216 & 0.000 & 0.967 & 1.147 & 0.863 & 0.863 & 0.863 \\
\hline
\end{tabular}

a Dependent Variable: Org_culture.

b Independent variable: El_leadership.

TABLE XI: MODEL SUMMARY

\begin{tabular}{|c|c|c|c|c|c|c|c|c|c|c|}
\hline \multirow[b]{2}{*}{ Model } & \multirow[b]{2}{*}{$\mathrm{R}$} & \multirow{2}{*}{$\begin{array}{c}\mathrm{R} \\
\text { Square }\end{array}$} & \multirow{2}{*}{$\begin{array}{l}\text { Adjusted R } \\
\text { Square }\end{array}$} & \multirow{2}{*}{$\begin{array}{l}\text { Std. Error of the } \\
\text { Estimate }\end{array}$} & \multicolumn{5}{|c|}{ Change Statistics } & \multirow{2}{*}{$\begin{array}{l}\text { Durbin } \\
\text { Watson }\end{array}$} \\
\hline & & & & & $\begin{array}{c}\text { R Square } \\
\text { Change }\end{array}$ & $\begin{array}{c}\mathrm{F} \\
\text { Change }\end{array}$ & df1 & df2 & $\begin{array}{l}\text { Sig. F } \\
\text { Change }\end{array}$ & \\
\hline 1 & $0.907^{\mathrm{a}}$ & 0.822 & 0.821 & 5.40369 & 0.822 & 850.833 & 1 & 184 & 0.000 & 1.976 \\
\hline
\end{tabular}

a. Predictors: (Constant), Org_culture.

b. Dependent Variable: Em_performance.

TABLE XII: ANOVA ${ }^{\mathrm{a}}$

\begin{tabular}{|c|c|c|c|c|c|c|}
\hline & & Mean Square & $F$ & Sig. \\
\hline & Regression & 24844.180 & 1 & 24844.180 & 850.833 & $0.000^{\mathrm{b}}$ \\
\hline 1 & Residual & 5372.771 & 184 & 29.200 & & \\
\hline & Total & 30216.952 & 185 & & & \\
\hline
\end{tabular}

a Dependent Variable: Em_performance.

b Predictors: (Constant), Org_culture

\begin{tabular}{|c|c|c|c|c|c|c|c|c|c|c|c|}
\hline & \multirow{2}{*}{ Model } & \multicolumn{2}{|c|}{$\begin{array}{c}\text { Unstandardized } \\
\text { Coefficients }\end{array}$} & \multirow{2}{*}{$\begin{array}{c}\begin{array}{c}\text { Standardized } \\
\text { Coefficients }\end{array} \\
\text { Beta }\end{array}$} & \multirow{2}{*}{$\mathrm{T}$} & \multirow{2}{*}{ Sig. } & \multicolumn{3}{|c|}{$\begin{array}{l}95.0 \% \text { Confidence Interval } \\
\text { for B } \\
\end{array}$} & \multicolumn{2}{|c|}{ Correlations } \\
\hline & & B & Std. Error & & & & $\begin{array}{l}\text { Lower } \\
\text { Bound }\end{array}$ & $\begin{array}{l}\text { Upper } \\
\text { Bound }\end{array}$ & $\begin{array}{l}\text { Zero- } \\
\text { order }\end{array}$ & Partial & Part \\
\hline \multirow[t]{2}{*}{1} & (Constant) & 13.060 & 1.525 & & 8.564 & 0.000 & 10.051 & 16.069 & & & \\
\hline & Org_culture & 0.672 & 0.023 & 0.907 & 29.169 & 0.000 & 0.627 & 0.718 & 0.907 & 0.907 & 0.907 \\
\hline
\end{tabular}

aDependent Variable: Em_performance.

b Independent Variable:Org_culture.

Sobel Test Equations

Sobel test:

$z$-value $=a^{*} b / \mathrm{SQRT}\left(b^{2 *} s_{\mathrm{a}}^{2}+a^{2 *} s_{\mathrm{b}}^{2}\right)$

Aroian test:

$z$-value $=a^{*} b / \mathrm{SQRT}\left(b^{2 *} s_{\mathrm{a}}^{2}+a^{2 *} s_{\mathrm{b}}{ }^{2}+s_{\mathrm{a}}{ }^{2} s_{\mathrm{b}}{ }^{2}\right)$

\section{Goodmantest:}

$z$-value $=a^{*} b / \mathrm{SQRT}\left(b^{2 *} s_{\mathrm{a}}{ }^{2}+a^{2 *} s_{\mathrm{b}}{ }^{2}-s_{\mathrm{a}}{ }^{2 *} s_{\mathrm{b}}{ }^{2}\right)$

Table XIV indicates that there is significant relationship between dependent and independent variables in the presence and non-presence mediator variables, which signifies that organizational culture and Ethical leadership are statistically significant with the employee's performance.

Table indicate the calculation of the critical ratio as a test of whether the indirect effect of the IV on the DV via the mediator is significantly different from zero.
TABLE XIV: THE SOBEL ANALYSIS

\begin{tabular}{|c|c|c|c|c|c|}
\hline & Input & Tests & Test statistic: & Std. Error: & $\begin{array}{c}\mathrm{P} \\
\text { value }\end{array}$ \\
\hline $\mathrm{a}$ & 1.057 & Sobel test & 18.0616974 & 0.03932654 & 0.000 \\
\hline $\mathrm{b}$ & 0.672 & Aroian test & 18.05516469 & 0.03934077 & 0.000 \\
\hline $\begin{array}{c}\mathrm{S}, \\
\mathrm{a}\end{array}$ & 0.046 & $\begin{array}{l}\text { Goodman } \\
\text { test }\end{array}$ & 18.068223719 & 0.0393123 & 0.000 \\
\hline \multirow[t]{2}{*}{$\mathrm{Sb}$} & 0.023 & & & & \\
\hline & Input & & Test statistic & $P$ value & \\
\hline $\mathrm{Ta}$ & 23.216 & Sobel test & 18.16480403 & 0.000 & \\
\hline \multirow[t]{2}{*}{$\mathrm{Tb}$} & 29.169 & Aroian test & 18.15827257 & 0.000 & \\
\hline & & $\begin{array}{c}\text { Goodman } \\
\text { test }\end{array}$ & 18.17134254 & 0.000 & \\
\hline
\end{tabular}

\section{Discussion}

This study was performed on three diverse variables, i.e., organizational culture, ethical leadership, and employee performance to see the effect of Organizational culture on the relationship between ethical leadership and employee performance.

Brown and Trevino [21] projected previously that moral role models utilize moral dimensions to enhance the performance of their workers. Organizational culture is the vital and most influential variable among the three, as it 
persuades the ethical leadership to augment the performance of the staff (employees). It is the foremost responsibility of the organization to provide their recruits a learning atmosphere.

Hence, it should be a joint effort by the leaders and workers to learn understand and implement.

\section{CONCLUSION}

The objective of the study is to examine the mediating role of organizational culture between ethical leadership and employee's performance. The research firstly focused on employee's performance then further assessment has been done through the testing ethical leadership on organizational culture and then to understand impact of the organizational culture on employee's performance.

The data for present study was collected from the SSGC Zonal office Jacobabad, Sub- Zonal Thull Talka district Jacobabad and Sub-Zonal office Kandhkot.

This research indicates that despite the vital importance of ethical leadership organization culture plays undeniable role in employees' performance and mentioned that how organization culture plays the mediating role between ethical leadership and employees' performance. With the support of ethical leaders' ethical context, it will further help to nurture the work efficiency of the employees.

From the current study it is observed that leader play significant role to create moral values and efficient culture within organization by providing equal opportunities for employees and give rewards on the performance without any distinction and also leaders invest in professional trainings and development for human workforce's efficient work and such practices directly influence the performance of the employees.

Along with that it is also observed from the results that organization is the key factor that play important mediating role between ethical leadership and employees' performance.

Results indicated that it is believed by respondents that the organizational environment and proper work distribution, individual and teamwork participation within the organization enhance the efficient culture of organization

And existing culture of SSGC observed from the facts and figures and concluded that employee's performance has significant influence of organizational culture of SSGC.

\section{A. Recommendations}

It is recommended after observation that regular trainings must be provided to employee for further improvement in skills of employees.

Further, highly qualified staff must be inducted in the organization to improve the management and organizational culture.

Ethical leader should Show a strong concern for ethical and moral values, fair and unbiased when assigning tasks to members, invest in professional training and development and he must practice what he preaches Executives.

The positive association between organization culture and performance helps in improving productivity of organization. For strong organization culture there must be efficient and effective management which ultimately is based on stronger work force. Healthy organizational culture improves and runs competitive environment.

The employee commitment helps in improving performance based organization sustainability.

And for successful run up Business decisions should be often made on the basis of facts, not just perceptions or assumptions

And the management style in the organization should be characterized by teamwork, consensus, participation.

Last but not the least Employee's should have good job knowledge with reference to core jobs.

\section{B. Limitations}

This research was based on employees of SSGC, offices of Jacobabad, Kandhkot and Thul were selected and working in different departments from top management to lowest.

The main cause of missing other offices was that majority of employee's was not always present there and the location was too far away to collect the data which is because of limited resources.

But through this study had opportunity to collect data from top management and lower management as well. While the majority who had this opportunity, were not approachable being active part of the decision making process in the departments of SSGC.

\section{Future Research Directions}

This research paper is directly related the Sui Southern Gas Company with variables ethical leadership, organization culture and employee's performance. Through this research covered the major sections and went for practical execution but other offices were not under observations hence future scholars can be to discover strategic role of organization culture to increases employee performance. Due to limited resources only one zonal office has been focused for research in future scholars can cover other areas of the country on all areas such as finance, HRM, supply chain and customers' feedback.

Ethical leadership is an asset of the organization towards employees for the efficiency; this study can also be extended to see the relationship of the ethical leadership with organizational commitment and development. Another aspect of the future research can be to see whether ethical leadership is negatively correlated with organization culture or employee performance.

\section{REFERENCES}

[1] Kanungo, R.N (2001) Ethical values of transactional and transformational leaders, Canadian Journal of Administrative Sciences / Revue Canadienne des Sciences de 1 Administration18(4):257-265.

[2] Brown Michael E., Treviño Linda K., Harrison (2005) David A. Ethical leadership: A social learning perspective for construct development and testing, Organizational Behavior and Human Decision Processes 97 (2005) 117-134.

[3] Trevino, L., \& Brown, M. (2004). Managing to be ethical: Debunking five business ethics myths. Academy of Management Executive, 18(2), 69-83

[4] Khuntia R, Suar D (2004). A Scale to Assess Ethical Leadership of Indian Private and Public Sector Managers, January 2004, Journal of Business Ethics ,49(1):13-26.

[5] Yukl, G. A. (2006). Leadership in organizations (6th ed.). Upper Saddle River, NJ: Pearson/Prentice Hall.

[6] O'Reilly, C.A., Chatman, J. III. \& Caldwell, D.F. 1991. 'People and organizational culture: Peters, Tom, and Robert Waterman. 1982. In Search of Excellence: Lessons from America's Best Run Companies. New York: Harper and Row. 
[7] Marcoulides, G. \& Heck, R. (1993). Organizational culture and performance: Proposing and testing a model. Organization Science, 4(2), 209-225.

[8] Mwita, J. I. (2000), Performance management model: A system-based approach to system quality. The International Journal of Public Sector Management, Volume 13, No. 1, pp. 19-37.

[9] Siraj Jamal and Masroor Ali Soomro., 2011. Management Styles and Employee Performance: A Study of a Public Sector Company (SSGC), South Asian Journal of Management Science, Vol. 5, No. 2, (Fall 2011)65-71.

[10] Habib, S. et al., 2014. The Impact of Organizational Culture on Job Satisfaction, Employess Commitment and Turn over Intention. Advances in Economics and Business, 2(6), 215-222.

[11] Iqbal, S. \& Guohao, L. A. S., 2017. Effects of Job Organizational Culture, Benefits, Salary on Job Satisfaction Ultimately Affecting Employee Retention. Review Pub Administration Manag 5: 229. doi:10.4172/2315-7844.1000229.

[12] Engelbrecht, A. S., Heine, G., \& Mahembe, B. (2017). Integrity, ethical leadership, trust and work engagement. Leadership \& Organization Development Journal, 38(3), 368-379.

[13] Xu, A. J., Loi, R., \& Ngo, H-Y. (2016). Ethical leadership behavior and employee justice Perceptions: The mediating role of trust in organization. Journal of Business Ethics, 134(3), 493-504.

[14] Azizollah, A., Abolghasem, F., \& Amin, D.M. 2016. The relationship between organizational culture and organizational commitment in Zahedan University of Medical Sciences. Global Journal of Health Science 8(7): 195-202.

[15] Dahie, A.M., Takow, M.A., Nur, A.H. \& Osman, M.M. 2016. Organizational culture and employee performance at telecommunication firms in Mogadishu, Somalia. International Journal in Commerce, IT \& Social Sciences 3(1): 30-41.

[16] Firuzjaeyan, A.A., Firuzjaeyan, M., \& Sadeghi, B. 2015. A survey of the effect of organizational culture on organizational commitment based on Allen and Meyer model (Case study: High school teachers of Bandpey region). International Journal of Academic Research in Business and Social Sciences 5(1): 1-9.

[17] Sui, A.S., Pearce, J.L., Porter, L.W. and Tripoli, A.M. (1997) Alternative Approaches to the Employee-Organization Relationship: Does Investment in Employees Pay Off? Academy of Management Journal, 40, 1089-1121. http://dx.doi.org/10.2307/256928.

[18] Rubin R.S,Dierdorff\&Michael E. Brown(2010) Does ethical leadership make a difference? Exploring leader and follower consequences of ethical leader behavior, Business Ethics Quarterly 20 (2):215-235 (2010).

[19] Eisenhardt, K. M. (1989). Building theories from case study research. Academy of Management Review, 14, 532-550. https://doi.org/10.2307/258557.

[20] Yin, R. K., (1994). Case Study Research Design and Methods: Applied Social Research and Methods Series. Second edn. Thousand Oaks, CA: Sage Publications Inc.

[21] Trevino, L.K., Brown, M.E. (2006), Ethical Leadership: A review and future directions. The Leadership Quarterly (Science Direct), 17, 595616.

[22] Argyris, C., \& Schön, D. (1996). Organizational learning. Reading, MA: Addison-Wesley.

[23] Ahmad, Shalik M. 2012. Impact of Organizational culture on Performance Management Practices in Pakistan, Business Intelligence Journal, 5.

[24] Alharbi. M and Alyahya. M (2013). Impact of Organizational Culture on Employee Performance: International Review of management and Business Research: Vol.2 Issue1.

[25] Aluko, M.A, 2003. The Impact of Culture on Organizational Performance in Selected Textile Forms in Nigeria, Journal of African Studies 12 (2): 164-79.

[26] Avolio, B. J., \& Gardner, W. L. (2005). Authentic leadership development: Getting to the root of positive forms of leadership. The Leadership Quarterly, 16(3), 315-338.

[27] Alvesson M. (2002). Understanding organizational culture. London, England: SAGE.

[28] Adel Mohamed Ali Shurbhagi \& Ibrahim Bin Zahari., 2014. The Mediating Effect of Organizational Commitment on the Relationship between Job Satisfaction and Organizational Culture. International Journal of Business Administration, Vol. 5, No. 6; 2014.

[29] Aroian, L. A. (1944/1947). The probability function of the product of two normally distributed variables. Annals of Mathematical Statistics, $18,265-271$.

[30] Argyris, C., \& Schön, D. (1996). Organizational learning. Reading, MA: Addison-Wesley.
[31] Ahmad, S., Shahzad, K. (2011), HRM and employee performance: A case of university teachers of Azad Jammu and Kashmir (AJK) in Pakistan. African Journal of Business Management, 5(13), 5249-5253.

[32] Al Nasseri, N., Osborne, A., Steel, G. (2013), Organizational culture, leadership style and effectiveness: A case study of middle eastern construction clients. In: Ahiaga-Dagbui, D.D., editor. Proceedings 29th Annual ARCOM Conference. p2-4.

[33] Avey, J. B., Palanski, M. E., \& Walumbwa, F. O. (2011). When Leadership Goes Unnoticed: The moderating role of follower SelfEsteem on the relationship between Ethical Leadership and Follower Behavior. Journal of Business Ethics, 98(4), 573-582.

[34] Baron, R. M., \& Kenny, D. A. (1986). The moderator-mediator variable distinction in social psychological research: Conceptual, strategic, and statistical considerations. Journal of Personality and Social Psychology, 51, 1173-1182.

[35] Denison D. R., Haaland S., Goelzer P. (2004). Corporate culture and organizational effectiveness: Is Asia different from the rest of the world?

[36] Dharmanegara, I.B.A., Sitiari, N.W. \& Adelina, M.E. 2016. The impact of organizational commitment, motivation and job satisfaction on civil servant job performance in State Plantation Denpasar. Journal of Business and Management (IOSR-JBM) 18(2): 41-50.

[37] Goodman, L. A. (1960). On the exact variance of products. Journal of the American Statistical Association, 55, 708-713.

[38] Hoyle, R. H., \& Kenny, D. A. (1999). Sample size, reliability, and tests of statistical mediation. In R. Hoyle (Ed.) Statistical Strategies for Small Sample Research. Thousand Oaks, CA: Sage Publications.

[39] Krull, J. L., \& MacKinnon, D. P. (1999). Multilevel mediation modeling in group-based intervention studies. Evaluation Review, 23, 418-444.

[40] MacKinnon, D. P., \& Dwyer, J. H. (1993). Estimating mediated effects in prevention studies. Evaluation Review, 17, 144-158.

[41] MacKinnon, D. P., Lockwood, C. M., Hoffman, J. M., West, S. G., \& Sheets, V. (2002). A comparison of methods to test mediation and other intervening variable effects. Psychological Methods, 7, 83-104.

[42] MacKinnon, D. P., Warsi, G., \& Dwyer, J. H. (1995). A simulation study of mediated effect measures. Multivariate Behavioral Research, 30, 41-62.

[43] Preacher, K. J., \& Hayes, A. F. (2004). SPSS and SAS procedures for estimating indirect effects in simple mediation models. Behavior Research Methods, Instruments, \& Computers, 36, 717-731.

[44] Shrout, P. E., \& Bolger, N. (2002). Mediation in experimental and nonexperimental studies: New procedures and recommendations. Psychological Methods, 7, 422-445.

[45] Sobel, M. E. (1982). Asymptotic intervals for indirect effects in structural equations models. In S. Leinhart (Ed.), Sociological methodology 1982 (pp.290-312). San Francisco: Jossey-Bass.

[46] Zahedi, M. 2004. Relationship between organizational culture and organizational performance, Tehran: Journal of the insurance industry, in the seventeenth, spring 2004. 